\title{
Effectiveness of selected disinfectants on Malassezia pachydermatis
}

\author{
J. Výrostková, E. Čonková, A. Laciaková, M. Pipová \\ University of Veterinary Medicine and Pharmacy in Košice, \\ Komenského 73,041 81 Košice, Slovakia
}

\begin{abstract}
The present study investigated the effectiveness of three different disinfectants: preparation H1 (two-component preparation based on hydrogen peroxide); Pedox (multi-component preparation based on peroxyacetic acid) and Savo hypochlorite preparation) against Malassezia pachydermatis. The antifungal activity of disinfectants was tested by quantitative suspension method according to STN EN 1650. The results confirmed $100 \%$ effectiveness of these disinfectants at all concentrations and exposure times tested.
\end{abstract}

Key words: Malassezia pachydermatis, disinfection, disinfectants

\section{Introduction}

Malassezia (M.) pachydermatis is a commensal, lipophylic, bazidiomycete of ovoid or ellipsoid shape with thick wall, without formation of pseudomycelium (Mason and Evans 1991). The effective therapy of malassezia, minimizing risk of recurrence, is based on both selection of suitable antimycotic and decontamination of the environment by suitable disinfectants. Increasing interest has been raised recently by the mixture of hydrogen peroxide and peracetic acid being considered harmless to the environment. Chlorine preparations which belong to the group of oxidants also show a very good disinfectant effect (Rodgers et al. 2001).

The aim of the study was to compare and evaluate effectiveness of three commercial preparations which, according to manufacturers, are sufficiently effective against microscopic fungi and yeasts including the yeast $M$. pachydermatis.

\section{Material and Methods}

The antifungal activity of disinfectants was tested by the standard method STN EN 1650 (2008). Three disinfectants were tested: H1 (two-component preparation, based on hydrogen peroxide, at concentrations $100 \%, 10 \%$ and 5\%); Pedox (multi-component preparation based on peracetic acid, at concentrations $3 \%, 1 \%$ and $0.5 \%$ ) and Savo (hypochlorite preparation, at concentrations $100 \%, 50 \%$ and $10 \%$ ).

The effectiveness of disinfectants was tested on 10 isolates of M. pachydermatis, obtained from animals with confirmed mycotic infection, and on reference strain M. pachydermatis 1879 (CBS, Utrecht, The Netherland). The quality control of the testing method was assessed by means of the yeast Candida albicans CCM 8215/ATTC 10231 (Czech Collection of Micro-organisms, Brno, Czech Republic). The reference strains were tested in duplicate. 
Suspensions containing $10^{6} \mathrm{CFU} / \mathrm{ml}$ of saline solution with $0.1 \%$ Tween 80 added were adjusted to the 1.0 (M. pachydermatis) or 0.5 (Candida albicans) McFarland turbidity standard. These suspensions were used to prepare $10^{6}-10^{1} \mathrm{CFU} / \mathrm{ml}$ dilutions to which individual disinfectants in specified concentrations were added. Dilutions without disinfectants added were used as a negative control. After 5, 10, and $15 \mathrm{~min}$ exposure the $0.1 \mathrm{ml}$ aliquots of suspension from each test-tube were inoculated on Sabouraud agar with chloramphenicol (HiMedia Laboratories Pvt. Ltd., Mumbai, India). The plates were incubated for $72 \mathrm{~h}$ at $32^{\circ} \mathrm{C}$ and then compared with the controls.

\section{Results and Discussion}

All the three preparations (H1, Pedox and Savo) showed $100 \%$ antifungal activity against 10 clinical isolates of $M$. pachydermatis, the standard strain of $M$. pachydermatis (CBS 1879) and Candida albicans (ATCC 10231) at each concentration tested.

Only several papers were devoted to the effectiveness of disinfectants on micromycetes (Moriello et al. 2002, Duarte and Hamdan 2006). The antifungal activity of three commercial disinfectants was tested in this study. Pedox is a mixture of water, hydrogen peroxide and peracetic acid. It acts more rapidly than hydrogen peroxide and shous bactericidal, sporocidal, virocidal and fungicidal activity (Bernstein 1990, Dostalová 2006). The main advantage of hydrogen peroxide as a disinfectant agent is that it leaves no residues as is decomposed to water and oxygen under the action of enzyme catalase (Ölmez et al. 2009). Hydrogen peroxide, as the principal ingredient of preparation H1, may be effective against a broad spectrum of micro-organisms including bacteria, yeasts, moulds and viruses (Votava et al. 2005) and also against parasits (Laciak et al. 2008). Hypochlorites are the most frequently used forms of active chlorine and among them sodium hypochlorite is used most widely. The manufacturer of Savo states that this preparation is effective against micro- scopic mycelial fungi, algae and lichens, and it also shows excellent bactericidal effects. The results of this study also confirmed the effectiveness of Savo against M. pachydermatis.

\section{References}

Bernstein M (1990) The chemistry of disinfectants, in Rommey, A.J.D. CIP: Cleaning in Place, Society of Dairy Technology. Huntington, pp 30-40.

Dostalová D (2006) Peroxo compounds for disinfection in health services and veterinary practice (In Czech). In: VIIth DDD Conference, Poděbrady, 15-16 May 2006, Sdružení DDD (Society of Disinfection, Disinsection, Deratization): Prague, pp 26 (abstract).

Duarte ER, Hamdan JS (2006) Susceptibility of yeast isolates from cattle with otitis to aqueous solution of povidone iodine and to alcohol-ether solution. Med Mycol 44: 369-373.

Laciak V, Laciaková A, Dionýz M, Severa J, Venglovsky J (2008) The influence of selected disinfectants on eggs of canine endoparasites (In Slovak). In: VIIth Ecology and veterinary medicine Conference, Proceedings, pp 185-189.

Mason KV, Evans AG, (1991) Dermatitis associated with Malassezia pachydermatis in 11 dogs. J Amer Animal Hosp Assn 27: 13-20.

Moriello KA, Deboer DJ, Volk L (2002) Determination of strain variability of Microsporum canis to disinfectants. Vet Dermatol 13: 211-229.

Ölmez H, Kretzschmar U (2009) Potential alternative disinfection methods for organic fresh-cut industry for minimizing water consumption and environmental impact. Food Sci Technol 42: 686-693.

Rodgers JD, Cullagh JJ, Namee PT, Smyth JA, Ball HJ (2001) An investigation into the efficacy of hatchery disinfectants against strains of Staphylococcus aureus associated with the poultry industry. Vet Microbiol 82: 131-140.

STN EN 1650 (2008) Quantitative suspension test for the evaluation of fungicidal or yeasticidal activity of chemical disinfectants and antiseptics used in food, industrial, domestic and institutional areas. (In Slovak) pp 32.

Votava M, S̈litrová J, Matušková Z (2005) Microbicidal efficacy of a new foam disinfectant. Epidemiol Mikrobiol Immunol 54: 84-89. 